\title{
Involvement of Bacillus Species in the Understanding of the Softening Process of Safou Pulp (Dacryodes Edulis H.J.Lam)
}

\author{
Nicaise Saturnin Mokemiabeka, Christian Aimé Kayath* and Brice Alain Vouidibio Mbozo \\ Cellular and Molecular Biology Laboratory (BCM), Marien Ngouabi University, Republic of Congo
}

*Corresponding author: Christian Aimé Kayath, Cellular and Molecular Biology Laboratory (BCM), Faculty of Science and Technology, Marien Ngouabi University, Brazzaville, Republic of Congo.

To Cite This Article: Nicaise Saturnin Mokemiabeka, Christian Aimé Kayath, Brice Alain Vouidibio Mbozo, Involvement of Bacillus Species in the Understanding of the Softening Process of Safou Pulp (Dacryodes Edulis H.J.Lam). Am J Biomed Sci \& Res. 2021 - 12(2). AJBSR.MS.ID.001729. DOI: 10.34297/AJBSR.2021.12.001729.

Received: 钢 February 24, 2021; Published: 制 March 09, 2021

\begin{abstract}
For the last twenty years, Biotechnology, including techniques for preserving of traditional fermented foods, has grown considerably. Safou, some fruit from Dacryodes edulis, is widely consumed in Africa but poses conservation problems because of its very rapid softening. In the Republic of Congo, a fermentation technique has been developed in order to preserve fruits. This work aims to study the bacteria of the genus Bacillus involved in the softening of Safou. Using classical microbiological techniques, we estimated the number of bacteria to be $2.5 \pm 0.7$. 102 FCFU/g from the softened safous and at $4 \pm 0.8 .106 \mathrm{CFU} / \mathrm{g}$ from the non-softened safous. By using PCR multiplex of fibE gene, Bacillus subtilis and Ballus safensis have been mostly ientified and strains have shown degradation percentages of pectin, amylose, proteolytic up to $55 \%$, 55\% and $63 \%$, respectively. $45 \%$ of isolates including Bacillus subtilis and Bacillus safensis can secrete pectinases, amylase and proteases. The assessment of Penetrometry index showed that B. subtilis and B. safensis are able to contribute to the softening of african pears.
\end{abstract}

Keywords: Safou; Fermentation; Preservation; PCR Multiplex; Bacillus

\section{Introduction}

Dacryodes edulis occurs naturally in the countries bordering the Gulf of Guinea. It is croping from Sierra Leone east to Angola along the Atlantic and further inland to Uganda. It has also been reported from northern Zimbabwe. Safou or African pears are typical fruits can be produced by Dacryodes edulis crop. The culture of Dacryodes edulis has spread an attracting growing interest and is currently in strong progression in the continent of Africa. In Africa population this fruit is well appreciate [1,2]. Safous have been found not only in Africa countries, but also it is exported in Europe including France, Nederland, Germany and Belgium. More and more the demand of safou on the Congolese market has become strong. But the local production is weak and african pear is still a seasonal fruit in the Republic of Congo. One of the major and worrying problems is the preservation of the safou. The post-harvest rot diseases of fruits of the African pear are one the economic concern in Africa [3,4]. In order to preserve fruits, the congolese people have developed a tradi tional strategy consisting in fermenting the safous and drying them. Most of the scientific research carried out on D. edulis has focused on the nutritional value of african pear pulp and oil extraction processes [5-7]. By drafting this paper no studies have been forcused to understand the fermentation process of safous. In addition, endogenous knowledge states that the safou once softened can be eaten or dried for future preservation. The microorganisms involved in the softening of african pear have not yet been studied. This study aims to speciffically the understanding in the role of Bacillus species in the softening of the traditional process of Safou preservation.

\section{Methods}

\section{Isolation of Microorganisms}

The safous freshly sold on stalls at the Total market in Brazzaville (Arrondissement 2, Bacongo) were purchased and transported in a cooler and sent to the laboratory as quickly as possible. The 
samples were sorted on the basis of texture. Those with a nice texture were stored at room temperature for 4 to 5 days to observe the softening process. At the end of 5 days of softening, the the pulp of safou was sample for microbiology assessment.

Dilutions were done, and microorganism suspension was streaked with Mossel supplemented with polymyxin B. Enumeration of colonies was done in triplicate on Plate Count Agar (PCA). The Petri dishes were incubated at $37^{\circ} \mathrm{C}$ for $24 \mathrm{~h}$ to $48 \mathrm{~h}$. After the first isolation on Petri dishes, each colony of different appearance was separately isolated. Purification of the isolates was rigorously done by successive and alternating subcultures. Purity was estimated by using a microscope for morphological characterization. Gram status was determined by using 3\% KOH. Sporulation, hydrogen peroxide $\left(\mathrm{H}_{2} \mathrm{O}_{2}\right)$, and oxidases tests were used for biochemical characterization.

\section{Determination of Proteolytic Activity}

Some Bacillus strains were assessed for the ability to secrete proteases as described and modified by Kaya-Ongoto et al, 2019 [8]. Briefly, $1 \mathrm{~g}$ of agarose was weighed and mixed with $100 \mathrm{ml}$ of PBS. The mixture was heated in a microwave for 3 min until agarose was completely dissolved and then cooled in a water bath at $40^{\circ} \mathrm{C}$. Then $10 \mathrm{ml}$ of skim milk was added to the mixture. After homogenization, the mixture was poured into the Petri dishes. Once solidified, wells were carefully and aseptically generated into the gels. A volume of $50 \mu \mathrm{l}$ of the overnight culture supernatant is deposited in the wells made on the medium composed of $1 \%$ agarose gel, $0.01 \mathrm{M}$ PBS, $\mathrm{pH}$ 7.4 and supplemented with skimmed milk. The Petri dishes are incubated at $37^{\circ} \mathrm{C}$ for 24 hours. The presence of proteolytic activity is detected by a clear halo around colonies indicating hydrolysis of casein. The halo diameter was measured.

\section{Amylolytic and Pectinolytic Activities}

To assess the amlylolytic, pectinolytic activity of isolates, an overnight culture in LB medium was carried out on a Petri dishes. Then a young bacterial colony was deposited on the surface on solid LB medium separately supplemented with $1 \%$ of starch $0.5 \%$ of pectin. The Petri dishes were incubated $24 \mathrm{~h}$ to $48 \mathrm{~h}$. The revelation is made with Lugol. A test is positive if there is a clear halo around the colony corresponding to a lysis range. The percentage of enzymatic activity was determined according to the following formula: $\%=$ DT-DC/DT with DT: Total lysis diameter (Lysis area + Colony diameter); DC: Colony diameter; \%: Percentage of lysis.

\section{Molecular Identification of Microorganisms}

The recent molecular identification developed in our laboratory using the amplification of $f i b E$ gene encoding for the fibrinolytic enzyme has been used to identify strains like B. amyloliquefaciens, B. subtilis, B. pumilus, B. licheniformis, B. altitudinis, B. mojavensis, $B$. safensis, and B. atrophaeus [8]. Briefly, extraction and purification of isolate genomic DNA were performed according to the Nucleo Spin Microbial DNA (Macherey-NAGEL) kit. Briefly, isolates were grown in $5 \mathrm{ml} \mathrm{LB}$ broth for $24 \mathrm{~h}$ at $37^{\circ} \mathrm{C}$ with stirring. The DNA purity was assessed by electrophoresis on agarose gel and by the ratio of optical densities $260 / 280 \mathrm{~nm}$. $5 \mu \mathrm{l}$ of each amplification product was mixed with $2 \mu \mathrm{l}$ of loading buffer (BIOKE). Mixtures were subjected to electrophoresis on $1 \%$ agarose gel $(\mathrm{w} / \mathrm{v}$ ). The $10 \mathrm{~kb}$ 2-Log (BIO$\mathrm{KE}$ ) was used as a molecular weight marker.

\section{The Influence of Identified Bacteria in the Softening}

The penetrometer resistance is an effective and reliable method for evaluating safou puple softening. A mecanic penetrometer has been used to introduce in softened African pears. Five overnight culture corresponding to NIc3, Nic32, Nic37, Nic39 and Nic45 were done. The pure culture has been assessed to reach 0.8 to 1 of D.O. Safou have been first washed with aseptic water and sterilized with $70 \%$ and $90 \%$ of ethanol. The aseptic safous were immersed for 5 to $10 \mathrm{~min}$ in each of the cultures and in the culture put together. The samples were stored at room temperature to follow the softening process. The penetrometry indices were calculated during the fermentation process. The values were established according to the texture of the softening safou. A score of ten (10) was associated with the safou who's the penetrometer completely has been penetrated. A score of five (5) was associated with the safou who's the penetrometer has not been completely penetrated. Zero $(0)$ was associated with the safou puple whose peak strength and maximum stress were not allowable.

\section{Result}

\section{Microbiological Assessment and Enzymatic Activities in the Softening of Safou}

A PCA medium have been used to enumerate bacteria. $2,5 \pm 0.7$. $10^{2} \mathrm{FCFU} / \mathrm{g}$ from softened safou and $4 \pm 0.8 .10^{6} \mathrm{CFU} / \mathrm{g}$ from non-softened african pear have been obtained. A total of 45 isolates have been ramdomly chosen for future experiments. Macroscopic and microscopic analysis, Gram-positive bacteria with $3 \% \mathrm{KOH}$, spore-forming bacteria test, and the positive catalase reaction had been allowed the classification of 24,4\% (11/45) working bacterium as candidates from the genus Bacillus. All eleven (11) bacteria were spore-forming colonies excepting for 75,6\% (34/45). To easily discriminate Bacillus spp. at the genera level, pure cultured isolates were assessed for their ability to produce proteases, pectinases and cellulase. A screening of the amylolytic, proteolytic and pectinolytic activities was carried out among 11 isolates with Bacillus oriented phenotype. The presence of enzymatic activities was detected by using starch, casein and pectin as following substrates (Figure 1). Among 11 isolates 55\% (6/11) were able to show a very interresting the clear halo in terms of amylolytic and pectinolytic activity (Figure 1) including Nic 3, 32, 37, 39, 42 and 43 strains. Neither activity was observed in $45 \%$ (5/11). This is concerning Nic1, 
$5,33,40$ and 45 . Regarding proteolytic activity $63 \%$ of isolates had postive activity including Nic1, 32, 33, 37, 39, 42 and 43. (Figure 1)

\section{Molecular Identification of Isolates}

A strategy has been implemented in our laboratory as part of a previous study. We therefore sought to identify by using this strategy. The 11 Bacillus-oriented bacteria which colonize Safou have been identified. After purification of the genomic DNA, amplifications of the $f i b E$ gene encoding the fibrinolytic enzymes (FibE) were carried out. By using 6 pairs of primers including Ba.IdMa-F/ Ba .IdMa-R for B. amyloliquefaciens, Bl.Id.Ma-F/Bl.Id.Ma-R for B. Iicheniformis, Bs.Id.Ma-F/Bs.Id.Ma-R for B. subtilis, Bp .Id.Ma-F/Bp.Id. Ma-R for B. pumilus, Bm.Id.Ma-F/Bm.Id.Ma-R for B. mojavensis, Bsa. Id.Ma-F/Bsa.Id. Ma-R for B. safensis. Isolates Nic3, 32 and 37 have been associated to Bacillus subtilis meanwhile isolates Nic39 and 49 avec been associate to Bacillus safensis (Figure 2). Nothing has been amplified Nic 3, 32, 40, 42, 43 and 45.
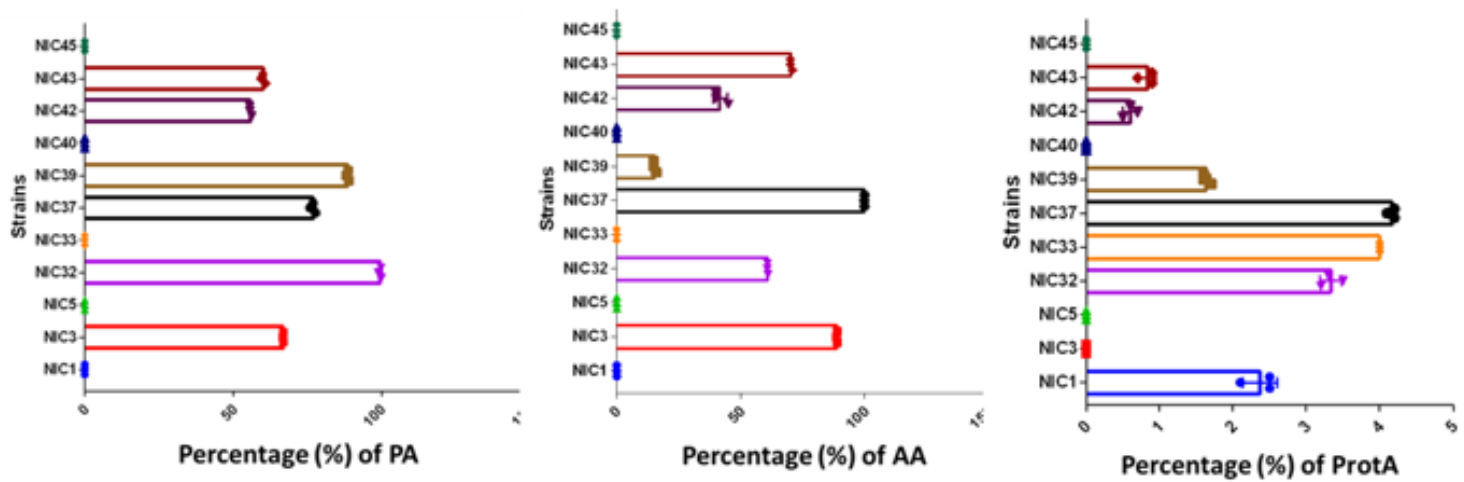

Figure 1: Enzymatic Activities of isolates in the softening of Safou. Left (Pectinolytic activity (PA)), Center (amylolytic activity (AA) and Right (Proteolytic activity (PA)). Nic3, Nic32, Nic33, Nic37, Nic40, Nic42 and Nic45: Bacteria isolated with Bacillus oriented phenotype.

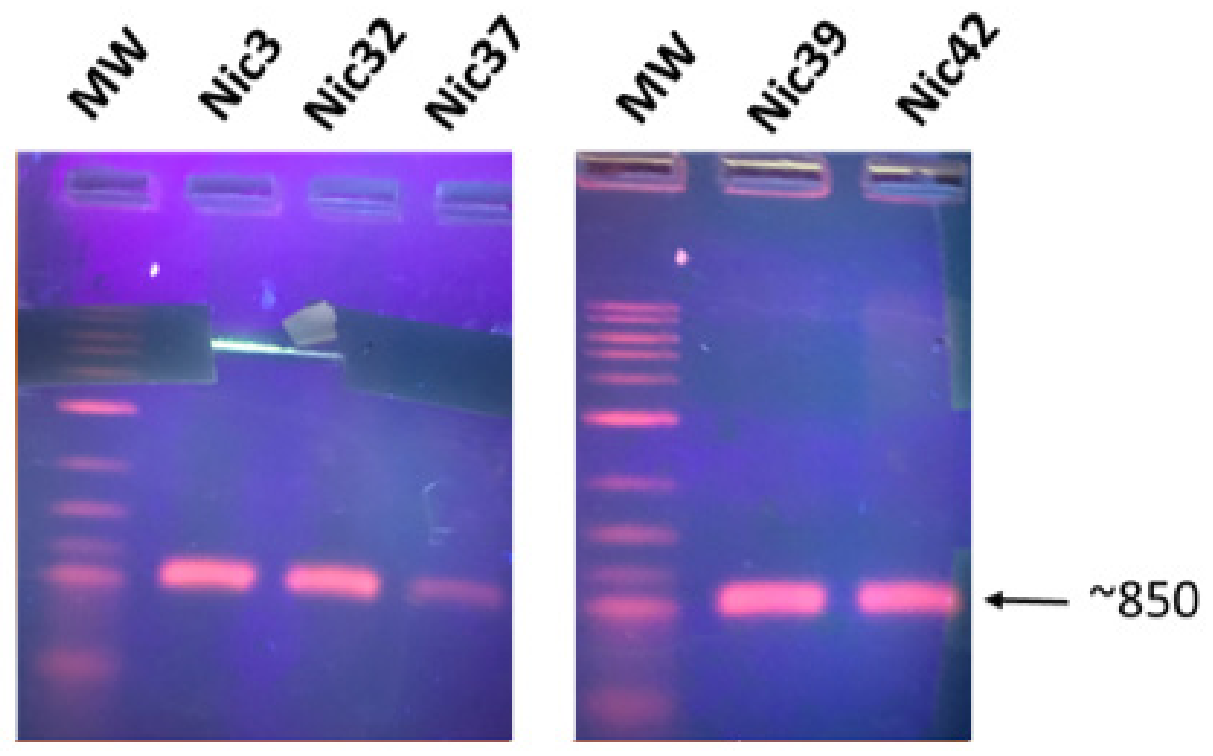

Figure 2: Molecular identification of isolates. MW: molecular weight. Nic3, 32, 37 are matching to Bacillus subtilis. Nic 39 and 45 are matching to Bacillus safensis.

\section{The Influence Bacillus in the Softening}

By mixing safou with the Bacillus cultures including Nic3, Nic32, Nic37, Nic39 and Nic45, the safous have been stocked at room temperature for softening. The penetrometry index have been calculated. As results we show that the strains were able to soften the safous more faster than expected. Bacillus Nic32 and Nic45 strains exhibited an interesting phenotype in softening the safou after two days. Finally, we assessed for consortium including both Nic32 and Nic45 strains. Safous were able to fastly soften after one day capare to the safous that were not mixed with the culturable bacteria (Figure 3). 


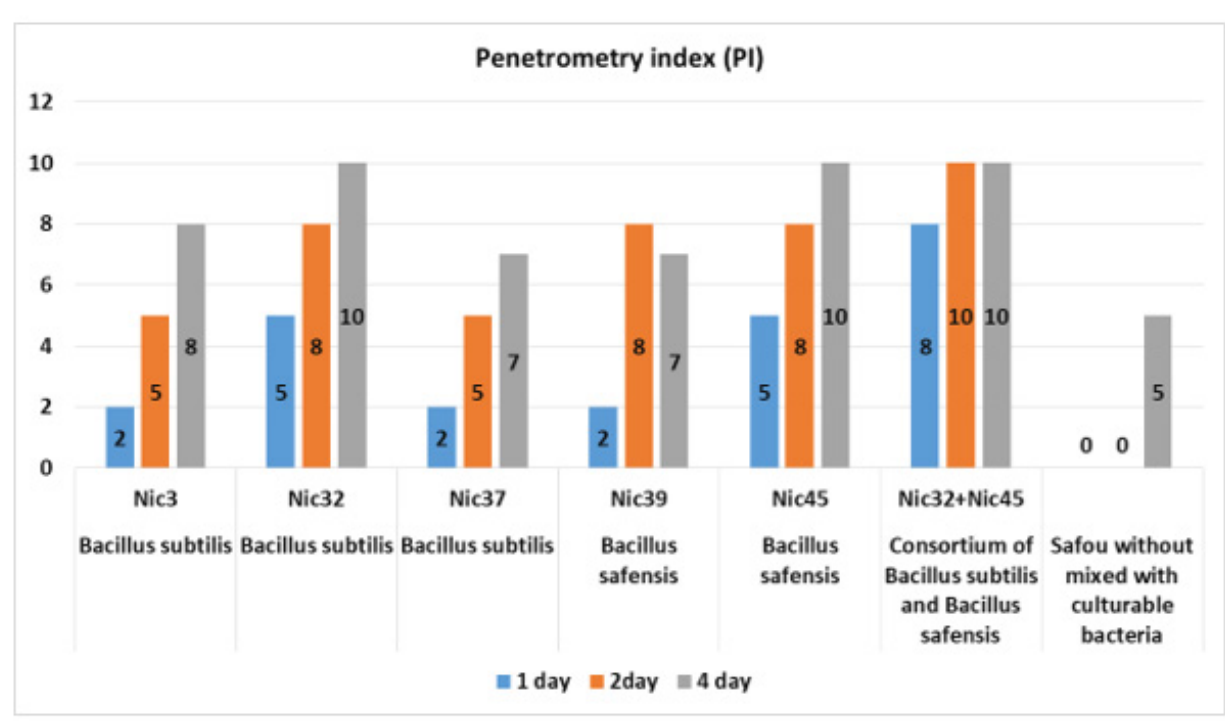

Figure 3: The Penetrometry Index ( $\mathrm{PI}$ ) of strains have been assessed during four (4) day of fermentation. Nic3, 32,37 are matching to Bacillus subtilis and Nic 39 and 45 are matching to Bacillus safensis.

\section{Discussion}

In this work we have worked on ripe fruits of safou collected in local markets in Brazzaville. One of major trouble shooting of safou comes to the short duration of natural softening. The post-harvest losses by natural softening of safou pulp have been studied [6]. This work aimed to isolate and to molecularly identify the microorganisms like Bacillus and to understand the enzymatic activities in the softening of safou. The isolation from ten (10) softened safou fruits showed a low enumeration rate which was around $2,5 \pm 0.7 \cdot 10^{2} \mathrm{Col}-$ ony Forming Unit per gram of material. This low rate would be due to the low specific activity of the water. Isolation of non-softened african pear has been compare with the softened safou. As result the numeration was about $4 \pm 0.8 .10^{6} \mathrm{CFU} / \mathrm{g}$. The softening combined with the loss of water could be a hallmark that stop the growth of other microorganisms. Microorganisms like Shigella, Salmonella, Lactic acid bactéria were not isolated at the end of softening.

The new strategy of the molecular identification of the genus Bacillus belonging to group I have been published by our research group. This study targeted Bacillus subtilis, B. amyloliquefasciens, $B$. licheniformis, B. pumilus B. safensis, B. altitudinis, B. mojavensis, $B$. circulans. The primer pairs chosen in that work targeted the amplification of fibE an encoding a fibrinolytic enzyme. Using the six (6) pairs of primers, we directly identified three (3) isolates corresponding to $B$. subtilis and two (2) isolates corresponding to $B$. safensis. Our inexpensive and rapid method has the advantage of avoiding gene sequencing steps [8].

Bacteria such as Bacillus thuringiensis have also been identified by a direct approach using primers which hybridize specifically on the cry gene of course without going through sequencing [9].
Another study on yeasts had shown that, thanks to the direct PCR approach, it was also possible to directly identify yeasts such as Saccharomyces cerevisiae, S. arboricola, S. bayanus, S. cariocanus, $S$. kudriavzevii, S. mikatae, S. paradoxus and S. pastorianus. All this by targeting specific genes belonging to these species [10].

Fruit softening is a major issue of multiple cellular processes, including extensive remodeling of cell wall structure [11]. The ripening of the fruits is a complex event and some molecular events occurring during softening of strawberry fruit have been documented [12]. It is obvious to admit that ripening of fruits like safou is also identified by the secretion of a range of pectin degrading enzymes in the cell wall, and changes in the structure of pectin could result from their synergistic combination with the physiology of the cell [11] and enzymes secreted by Bacillus. The flesh of the fruit is softened by enzymes that break down cell walls. The natural action of these enzymes is dependent on the temperature [13] and would be accelerated by the enzymes produced by bacteria of the genus Bacillus.

The genus Bacillus is known for its ability to produce extracellular enzymes such as amylases pectinases, proteases [14-17]. In this study we demonstrated the correlation between the secretion of enzymes and safou softening. In the context of this work some identified isolates have shown degradation percentages of pectin amylose, proteolytic up to $55 \%, 55 \%$ and $63 \%$, respectively. $45 \%$ of isolates including Nic32, 37, 39, 42 and 43 can secrete in the same time enzyme as molecules including pectinases, amylase and proteases. All the enzymatic background could contribute to the biodegradation of the wall cell of the safou. This also could allow the release of other cytosol enzymes being inside the plant cells of the 
safou. The enzymatic activities carried out have shown that bacteria of the genus Bacillus are able to secrete lytic enzymes produced during the softening that could contribute to the degradation of cell wall structures. It has been documented that softening is a hallmark of fermentation in most modern or traditionnal fermented food [18-21].

\section{Conclusion}

There is a bright future for african pear generally appreciated for its health benefits. In view of the afore informations, there is an involvement of microorganisms in the softening of the pulp of safou. The softening process is orchestrated by the coordinated secretion of enzymes such as proteases, pectinases and proteases by the genus Bacillus belonging to the phylogenic group I. This work seems to be very important for the valorization of the african pear. Several enzymatic activities can be studied, such as lipolytic and cellulosic activity, which may also help explain the softening of safous. We plan to continue this work by studying the protein profile and molecular identification of all cultivable flora.

\section{Acknowledgement}

None.

\section{Conflict of Interest statement}

No conflict of interest.

\section{References}

1. Omoti U, Okiy DA (1987) Characteristics of the pulp oil and cake of the African pear, Dacryodes edulis (G. Don) HJ Lam. J Sci Food Agric 38: $67-$ 72

2. Okafor JC (1983) Varietal delimitation in Dacryodes edulis (G. Don) H.J Lam (Burseracea). Int Tree Corps J 2: 255-265.

3. Ayuk ET, Duguma B, Franzel S, Kengué J, Mollet M, et al. (1999) Uses, management, and economic potential of Dacryodes edulis (Burseraceae) in the humid lowlands of Cameroon. Economic Botany 53(3): 292-301.

4. Nwufo MI, Emebiri LC, Nwaywu MY (1989) Post-harvest rot diseases of fruits of the African pear (Dacryodes edulis) in South Eastern Nigeria. Tropical Science 29: 247-254.

5. Dzondo Gadet M, Nzikou JM, Matouba E, Etoumongo A, Linder M, et al. (2005) Characterisation and nutritional interest of safou pulp oil. Process Biochemistry 40(1): 307-312.

6. Silou T, Massamba D, Goma Maniongui J, Maloumbi G, Biyoko S. (2007) Post-harvest losses by natural softening of safou pulp (Dacryodes edulis) in Congo-Brazzaville. Journal of Food Engineering 79(2): 392-400.
7. Onocha PA, Ekundayo O, Oyelola O, Laakso I (1999) Essential oils of Dacryodes edulis (G.Don) H.J.Lam (African pear). Flavour and Fragrance Journal 14: 135-139.

8. Kaya Ongoto MD, Kayath CA, Nguimbi E, Lebonguy AA, Nzaou SAE, et al. (2019) Genetic Clearness Novel Strategy of Group I Bacillus Species Isolated from Fermented Food and Beverages by Using Fibrinolytic Enzyme Gene Encoding a Serine-Like Enzyme. J Nucleic Acids pp: 5484896.

9. Porcar M, Juarez Perez V (2003) PCR-based identification of Bacillus thuringiensis pesticidal crystal genes. FEMS Microbiol Rev 26(5): 419 432 .

10. Muir A, Harrison E, Wheals A (2011) A multiplex set of species-specific primers for rapid identification of members of the genus Saccharomyces. FEMS Yeast Res 11(7): 552-563.

11. Wang D, Yeats TH, Uluisik S, Rose JKC, Seymour GB (2018) Fruit Softening: Revisiting the Role of Pectin. Trends Plant Sci 23(4): 302-310.

12. Moya Leon MA, Mattus Araya E, Herrera R (2019) Molecular Events Occurring During Softening of Strawberry Fruit. Front Plant Sci 10: 615.

13. Okolie PN, Obasi BN (1992) Implication of cell wall degrading enzymes in the heat-induced softening of the African pear (Dacryodes edulis (G. Don) H.J. Lam). Journal of the Science of Food and Agriculture 59: 59-63.

14. Yu P, Xu C (2018) Production optimization, purification and characterization of a heat-tolerant acidic pectinase from Bacillus sp. ZJ1407. Int J Biol Macromol 108: 972-980.

15. Mahto RB, Yadav M, Sasmal S, Bhunia B (2019) Optimization of Process Parameters for Production of Pectinase using Bacillus Subtilis MF447840.1. Recent Pat Biotechnol 13(1): 69-73.

16. Heo K, Cho KM, Lee CK, Kim GM, Shin JH, et al. (2013) Characterization of a fibrinolytic enzyme secreted by Bacillus amyloliquefaciens CB1 and its gene cloning. J Microbiol Biotechnol 23(7): 974-983.

17. Yao Z, Kim JA, Kim JH (2019) Characterization of a Fibrinolytic Enzyme Secreted by Bacillus velezensis BS2 Isolated from Sea Squirt Jeotgal. J Microbiol Biotechnol 29(3): 347-356.

18. Chen YH, Liu XW, Huang JL, Baloch S, Xu X, et al. (2019) Microbial diversity and chemical analysis of Shuidouchi, traditional Chinese fermented soybean. Food Res Int 116: 1289-1297.

19. Wacoo AP, Mukisa IM, Meeme R, Byakika S, Wendiro D, et al. (2019) Probiotic Enrichment and Reduction of Aflatoxins in a Traditional African Maize-Based Fermented Food. Nutrients 11(2): 265.

20. Ouoba LI, Rechinger KB, Barkholt V, Diawara B, Traore AS, et al. (2003) Degradation of proteins during the fermentation of African locust bean (Parkia biglobosa) by strains of Bacillus subtilis and Bacillus pumilus for production of Soumbala. J Appl Microbiol 94(3): 396-402.

21. Ouoba LI, Parkouda C, Diawara B, Scotti C, Varnam AH (2008) Identification of Bacillus spp. from Bikalga, fermented seeds of Hibiscus sabdariffa: phenotypic and genotypic characterization. J Appl Microbiol 104(1): 122-131. 